\title{
PENGARUH CORPORATE SOCIAL RESPONSIBILITY DAN PERATAAN LABA TERHADAP RESPON INVESTOR DALAM SEKTOR KEUANGAN (Studi empiris pada perusahaan Sektor keuangan di BEI periode 2013-2015)
}

\author{
Tuti Juniarsih
}

Fakultas Ekonomi dan Bisnis Universitas Muhammadiyah Purwokerto

Wida Purwidianti

Fakultas Ekonomi dan Bisnis Universitas Muhammadiyah Purwokerto

\begin{abstract}
The Research aimed to test effect of corporate social responsibility and profit equalization on investor's response. independent variables in this study were corporate social responsibility and profit equalization. Dependent variable of this study was investor's response (Cummulative abnormal return). This study used four control variables, those were: return on assets (ROA), debt to equity ratio (DER), firm size (FSIZE), and market share (MSHARE). This study was a quantitative research. The object of this study were financial firms listed on Indonesia Stock Exchange (BEI), There were 102 samples in this study obtained by using purposive sampling. Data analysis technique used in this research were descriptive statistics test, classical assumption test, multiple regression analysis, and hypothesis testing. The analysis showed that corporate social responsibility gave negative and significant effect partially on CAR. Profit equalization gave positive and insignificant partially on CAR.
\end{abstract}

Keywords: Corporate Social Responsibility, Investor's Response, Cumulative, Abnormal Return, Profit Equalization, Financial Sector.

\begin{abstract}
ABSTRAK
Penelitian ini bertujuan untuk menguji pengaruh Corporate Social Responsibility dan perataan laba terhadap respon investor. Variabel independen dalam penelitian ini adalah corporate social responsibility dan perataan laba, sedangkan variabel dependennya adalah Respon Investor (Cummulative abnormal return). Penelitian ini menggunakan empat variabel kontrol yaitu Return on asset (ROA), Debt to equity ratio (DER), Ukuran perusahaan (FSIZE) dan Market share (M SHARE) .Jenis penelitian yang digunakan dalam penelitian ini adalah penelitian kuantitatif. Objek penelitian ini adalah Perusahaan sektor keuangan yang terdaftar di Bursa Efek Indonesia (BEI), penelitian ini menggunakan 102sampelTeknik pengambilan data yang digunakan adalah purpossive sampling sementara teknik amalisis data yang digunakan dalam penelitian ini yaitu uji statistik deskriptif uji asumsi klasik, analisis regresi berganda dan pengujian hipotesis. Hasil analisis menunjukkan bahwa secara parsial corporate socialresponsibility secara parsial berpengaruh negatif dan signifikan terhadap Respon Investor (CAR). Sementara itu perataan laba secara parsial berpengaruh positif dan tidak signifikan terhadap Respon Investor (CAR).
\end{abstract}

Kata kunci : Corporate social responsibility, respon investor, cumulative abnormal return, perataan laba, sektor keuangan 


\section{PENDAHULUAN}

Dalam pengambilan keputusan investasi di pasar modal investor mempertimbangkan banyak hal dan membutuhkan informasi untuk pengambilan keputusan. Corporate Social Responsibility (CSR) dipandang sebagai bagian yang terintegrasi dengan strategi perusahaan. perkembangan isu CSR telah mendorong banyak peneliti untuk membuktikan pengaruh CSR terhadap respon investor, salah satu isunya yaitu perusahaan semakin banyak menerapkan CSR baik dalam bentuk amal (charity) maupun pemberdayaan (enpowerment). Berdasarkan survey awal peneliti pada November 2016, dari 10 perusahaan dalam sektor keuangan yang terdaftar di Bursa Efek Indonesia yang terpilih telah melakukan kegiatan CSR. Dibuktikan dengan hasil yang di peroleh dari perhitungan antara item yang di ungkapkan perusahaan di bagi dengan jumlah indikator yang di dapat dari Global Reporting Initiative (GRI) di dapatkan hasil bahwa perusahaan telah melakukan kegiatas CSR, walaupun belum secara maksimal. Dan setiap perusahaan melakukan kegiatan CSR dengan berbeda-beda, dilihat dari hasil yang diperoleh dari perhitungan tersebut.

Selain CSR, terdapat juga sumber lain yang dijadikan sebagai acuan atau pandangan bagi investor untuk pengambilan keputusan investasi, yaitu perataan laba. Di Indonesia telah banyak dilakukan penelitian mengenai pengaruh perataan laba terhadap respon Investor, namun masih terdapat pertentangan hasil penelitian. Hasil penelitian Assih dan Gudono (2000) serta Nasir, Arifin dan Susanti (2002) menunjukkan bahwa respon Investor atas pengumuman laba terdapat perbedaan antara perusahaan yang melakukan perataan laba dengan perusahaan yang tidak melakukan perataan laba. Harahap (2003) menyimpulkan bahwa perataan laba berhubungan positif terhadap koefisisen respon laba atau dengan kata lain pasar merespon laba yang dihasilkan dari praktik perataan laba. Perataan laba merupakan suatu bentuk manipulasi atas laba yang dilakukan manajer untuk mengurangi fluktuasi laba perusahaan, sehingga diharapkan kinerja perusahaan akan terlihat lebih bagus dan investor akan lebih mudah memprediksi di masa depan. Untuk mengetahui respon dari investor dapat dihitung dengan menggunakan Cumulative Abnormal Return (CAR) yang merupakan proksi dari respon investor. Respon investor merupakan tanggapan investor atas informasi yang diterimanya. Informasi yang diterima oleh investor akan dijadikan pedoman dalam pengambilan keputusan investasi. Informasi yang diterima oleh investor dapat mempengaruhi harga pasar sekuritas dalam pasar modal. Reaksi pasar dan respon investor merupakan konstrak yang sama. Subekti (2005) menyatakan bahwa reaksi pelaku pasar modal terhadap informasi yang dipublikasikan di pasar modal dapat diproksikan dengan efisien pasar, maka semakin cepat informasi tersebut terefleksi dalam harga saham. Variabel abnormal return. Perubahan harga saham akan dapat menggambarkan bentuk efisiensi pasar modal. Semakin

\section{TINJAUAN PUSTAKA}

Dalam penelitian ini, objek penelitian yang digunakan adalah perusahaan yang bergerak di sektor keuangan. Penelitian ini berbeda dengan penelitian- penelitian sebelumnya yang sebagian besar menggunakan objek penelitian dari semua sektor industri, sedangkan seharusnya tiap sektor industri memiliki kondisi yang saling berbeda. Adapun penelitian yang menggunakan sampel perusahaan dari sektor industri tertentu, perusahaan dari sektor keuangan masih belum pernah diteliti sebelumnya. Berdasarkan pertimbangan diatas, maka penelitian ini dilakukan untuk mengetahui apakah penerapan CSR dan Perataan laba yang dilakukan perusahaan yang terdaftar di Bursa Efek Indonesia dalam sektor keuangan berpengaruh terhadap Respon Investor.

\subsection{Pengaruh CSRI terhadap Respon Investor (CAR)}

Respon negatif yang diberikan oleh investor dikarenakan adanya anggapan investor bahwa perusahaan yang melakukan praktik CSR cenderung melakukan pemborosan sumber daya karena untuk melakukan CSR dibutuhkan sumber daya yang banyak dan belum tentu membawa dampak yang dapat dirasakan secara langsung oleh perusahaan. pernyataan tersebut didukung oleh Istianingsih dan Zulni (2013) yang dilakukan di Indonesia, menyatakan bahwa adanya pengaruh negatif antara CSR dan abnormal return dikarenakan biaya yang dikeluarkan perusahaan untuk aktivitas CSR akan semakin besar sehingga mengurangi laba perusahaan dan mengurangi pendapatan yang akan diperoleh investor.

$\mathrm{H}_{1}$ : CSRI berpengaruh negatif terhadap Respon Investor (CAR)

\subsection{Pengaruh Perataan Laba Terhadap Respon Investor}

Perataan laba merupakan tindakan yang dilakukan dengan sengaja untuk mengurangi risiko pasar atas saham perusahaan, yang pada akhirnya dapat meningkatkan harga pasar perusahaan. diharapkan reaksi pasar akan lebih kuat untuk pengumuman laba perusahaan yang melakukan perataan laba daripada untuk pengumuman perusahaan yang tidak melakukan perataan laba. Sebagaimana yang ditemukan oleh Resyuningdiah (2011) dalam Apriwandi (2011) bahwa abnormal return antara perusahaan perataan laba dan bukan perataan laba berbeda secara signifikan.

$\mathrm{H}_{2}$ : Perataan laba berpengaruh positif terhadap Respon Investor (CAR)

\section{METODE PENELITIAN}


Teknik analisis dalam penelitian ini menggunakan analisis regresi berganda. Hubungan antara variabel yang diuji dalam penelitian ini dapat dinyatakan dalam model persamaan sebagai berikut:

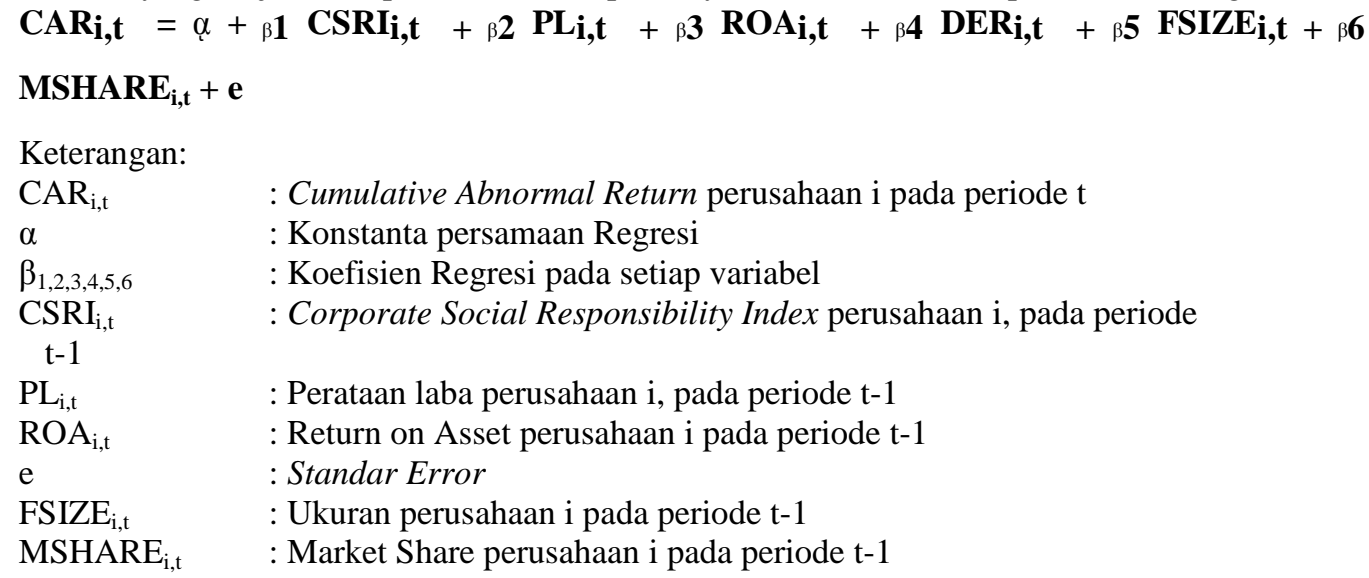

\subsection{Respon Investor (CAR)}

Tahap-tahap perhitungan CAR dalam penelitian ini mengacu pada tahapan dalam Arya \& Zhang (2009) dalam Sidharta dan Juniarti (2015), yaitu sebagai berikut :

1. Mengestimasi hubungan antara actual return (Rit) dan Market return (Rmt) untuk memperoleh expected return $\mathrm{Ri}, \mathrm{t}=\alpha \mathrm{i}+\beta \mathrm{i} \mathrm{Rmt}+{ }^{\mathrm{it}}$

2. Menghitung Abnormal Return (AR) yang merupakan selisih dari actual return dan expected retun.

AR i,t $=\mathrm{Ri}, \mathrm{t}-(\alpha \mathrm{i}+\beta \mathrm{i} \mathrm{Rmt})$

3. Menghitung jumlah abnormal return selama 11 hari (5 hari sebelum, 5 hari penyampaian laporan tahunan, dan 5 hari sesudah)

$$
\mathrm{CARi}, \mathrm{t}=\sum \mathrm{AR} \mathrm{i}, \mathrm{t}
$$

\subsection{Corporate Social Responsibility Indeks (CSRI)}

Dalam penelitian ini, CSR diukur dengan menggunakan CSR Index (CSRI), mengacu pada kriteria yang ditetapkan oleh Global Reporting Initiative yang mencakup pengungkapan CSR dalam bidang ekonomi, lingkungan, dan sosial. Tahap-tahap untuk memperoleh CSR index adalah sebagai berikut :

1. Memperoleh kriteria pengungkapan CSR dari Global Reporting Initiative.

2. Membandingkan kriteria dengan pengungkapan aktivitas CSR dalam laporan tahunan dan laporan tahunan secara keseluruhan, jika memenuhi kriteria diberi angka 1, jika tidak diberi angka 0 .

3. Menjumlahkan skor tiap perusahaan dalam 1 tahun lalu dibandingkan dengan jumlah kriteria keseluruhan untuk mengukur proporsi perusahaan dalam memenuhi kriteria pengungkapan tersebut, dengan rumus sebagai berikut :

$\mathrm{CSRI}_{\mathrm{i}, \mathrm{t}}=\sum \frac{\text { item yang diungkapkan }}{\text { item } \text { kriteria }}$

\subsection{Perataan Laba (PL)}

Perataan laba dalam penelitian ini diukur dengan menggunakan Indeks Eckel (1981) yang membedakan antara perusahaan perata laba dengan perusahaan bukan perata laba. Rumusnya adalah :

Indeks Perataan Laba $=(C V \Delta I / C V \Delta S)$ Keterangan :

$\Delta \mathrm{I} \quad=$ perubahan laba dalam satu periode

$\Delta \mathrm{S}=$ perubahan penjualan dalam satu periode $\mathrm{CV} \Delta \mathrm{I}=$ koefisien variasi untuk perubahan laba $\mathrm{CV} \Delta \mathrm{S}=$ koefisien variasi untuk perubahan penjualan

$\mathrm{CV} \Delta \mathrm{I}=\mathrm{CV} \Delta \mathrm{S}$ dapat dihitung dengan rumus:

$$
\mathrm{CV} \Delta \mathrm{I}=\sqrt{\frac{\sum\left(1 /-\overline{\Delta l}^{2}\right)}{n^{-1}} / \overline{\Delta l}} \quad \mathrm{CV} \Delta \mathrm{S}=\sqrt{\frac{\sum\left(S-\overline{\Delta S}^{2}\right.}{n^{-}-1}} / \overline{\Delta S}
$$

Keterangan :

$\Delta \mathrm{I} \quad=$ perubahan laba dalam satu periode

$\Delta \mathrm{S} \quad=$ perubahan penjualan dalam satu periode 
$\mathrm{n} \quad=$ jumlah tahun yang diamati

Perusahaan diklarifikasikan sebagai bukan perata laba jika:

$\mathrm{CV} \Delta \mathrm{I} \geq \mathrm{CV} \Delta \mathrm{S}$

Variabel ini merupakan variabel dummy, angka satu untuk perusahaan perata laba dan nol untuk perusahaan bukan perata laba.

\subsection{Return-On -Asset (ROA)}

Return-on-Asset (ROA) merupakan kemampuan suatu perusahaan dalam menghasilkan laba atas sejumlah aset yang dimilikinya (Almira, Shonhadji, Anggraini, 2009 dalam Anderson dan juniarti, 2015). Menurut Gamayuni (2012), dituliskan bahwa semakin tinggi rasio ini dapat menunjukkan penggunaan aset perusahaan semakin baik dan semakin tinggi profit yang diperoleh. Berikut rumus untuk mencari nilai ROA:

ROAi,t $=\frac{\text { Laba bersih }}{\text { Total Aset }}$

\subsection{Debt-to-Equity Ratio (DER)}

Debt to Equity Ratio (DER) merupakan salah satu rasio leverage (solvabilitas) yang mengukur kontribusi modal sendiri dan investasi jangka panjang dalam struktur permodalan perusahaan. Berdasarkan definisi tersebut maka Debt to Equity Ratio dapat dirumuskan sebagai berikut :

DERi,t $=\frac{\text { Total Kewajiban }}{\text { Total Ekuitas }}$

\subsection{Ukuran Perusahaan (FSIZE)}

Ukuran perusahaan adalah suatu skala yang dapat menujukkan dan mengklarifikasikan besar kecilnya suatu perusahaan (Aryani, 2011).Pengukuran ukuran perusahaan dengan total ase paling umum dilakukan. Dalam penelitian ini ukuran perusahaan dapat dirumuskan sebagai berikut:

FSIZE $_{i, \mathrm{t}}=\log$ total asset

\subsection{Market Share (MSHARE)}

Market share merupakan salah satu indikator makro yang dapat menjelaskan tentang kemampuan perusahaan dalam menguasai bagian pasar dalam sektor industrinya. Dalam penelitian ini, market share dapat dirumuskan sebagai berikut :

MSHARE $=\frac{\text { Total Penjualan }}{\text { Total Penjualan Industri }}$

\section{HASIL DAN PEMBAHASAN}

Penelitian ini dilakukan dengan menggunakan sampel penelitian yang berjumlah 102 sampel, yang merupakan hasil seleksi dari perusahaan yang bergerak dalam sektor keuangan yang terdaftar di Bursa Efek Indonesia berdasarkan kriteria-kriteria yang telah ditetapkan.

Tabel 1.

Hasil Statistik Deskriptif Descriptive Statistics

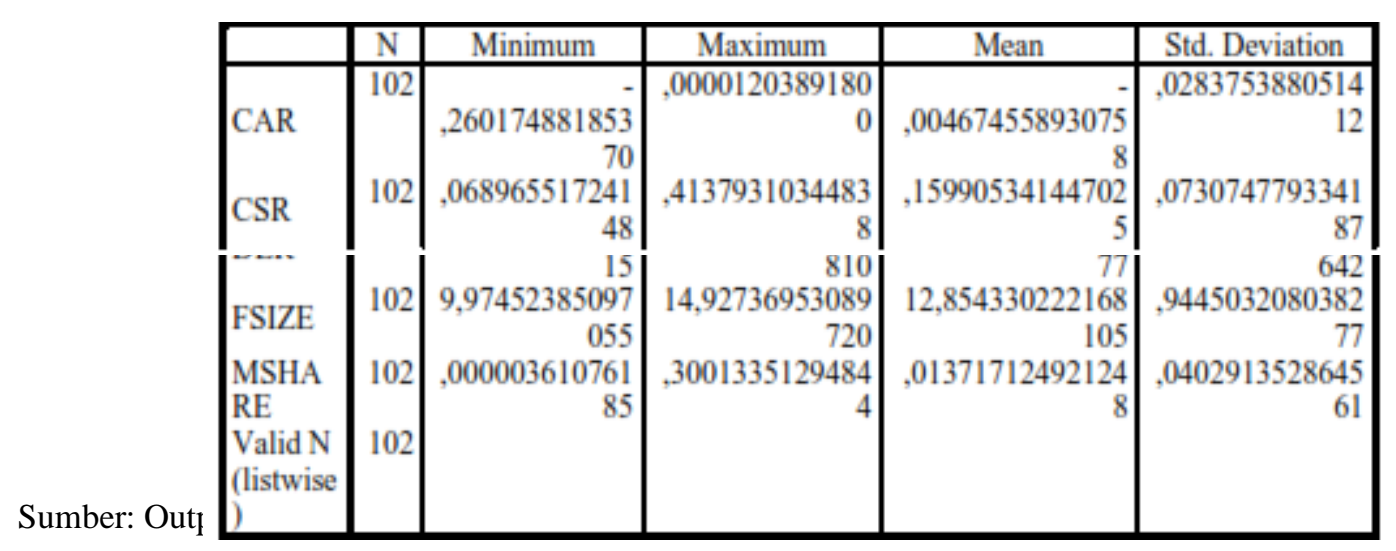

Tabel 1 menunjukkan nilai minimum, maksimum, rata-rata, dan standar deviasi masing-masing 
variabel dalam penelitian ini.

Tabel. 2

Hasil Uji Normalitas

One-Sample Kolmogorov-Smirnov Test

\begin{tabular}{|c|c|c|}
\hline & $\begin{array}{l}\text { Unstandardiz } \\
\text { ed Residual }\end{array}$ \\
\hline & & 77 \\
\hline Mean & & ,0000000 \\
\hline Normal Parameters ${ }^{a, b}$ & Std. & ,00000184 \\
\hline & Deviation & ,106 \\
\hline & Absolute & ,106 \\
\hline Most Extreme & Differences &,- 068 \\
\hline & Positive Negative & ,932 \\
\hline Kolmogorov-Smirnov 2 & & \\
\hline Asymp. Sig. (2-tailed) & & \\
\hline
\end{tabular}

a. Test distribution is Normal. b. Calculated from data.

Sumber: Output Spss 21, 2017

Tabel 2 menunjukkan hasil pengujian normalitas pada variabel residual yang dilakukan dengan menggunakan Kolomogorov Smirnov yang menunjukkan angka signifikansi 0,350 yang berarti bahwa nilai tersebut lebih besar dari 0,05. Dengan demikian dapat disimpulkan bahwa data terdistribusi secara normal.

Tabel. 3

\section{Uji Multikolinearitas}

Coefficients $^{\text {a }}$

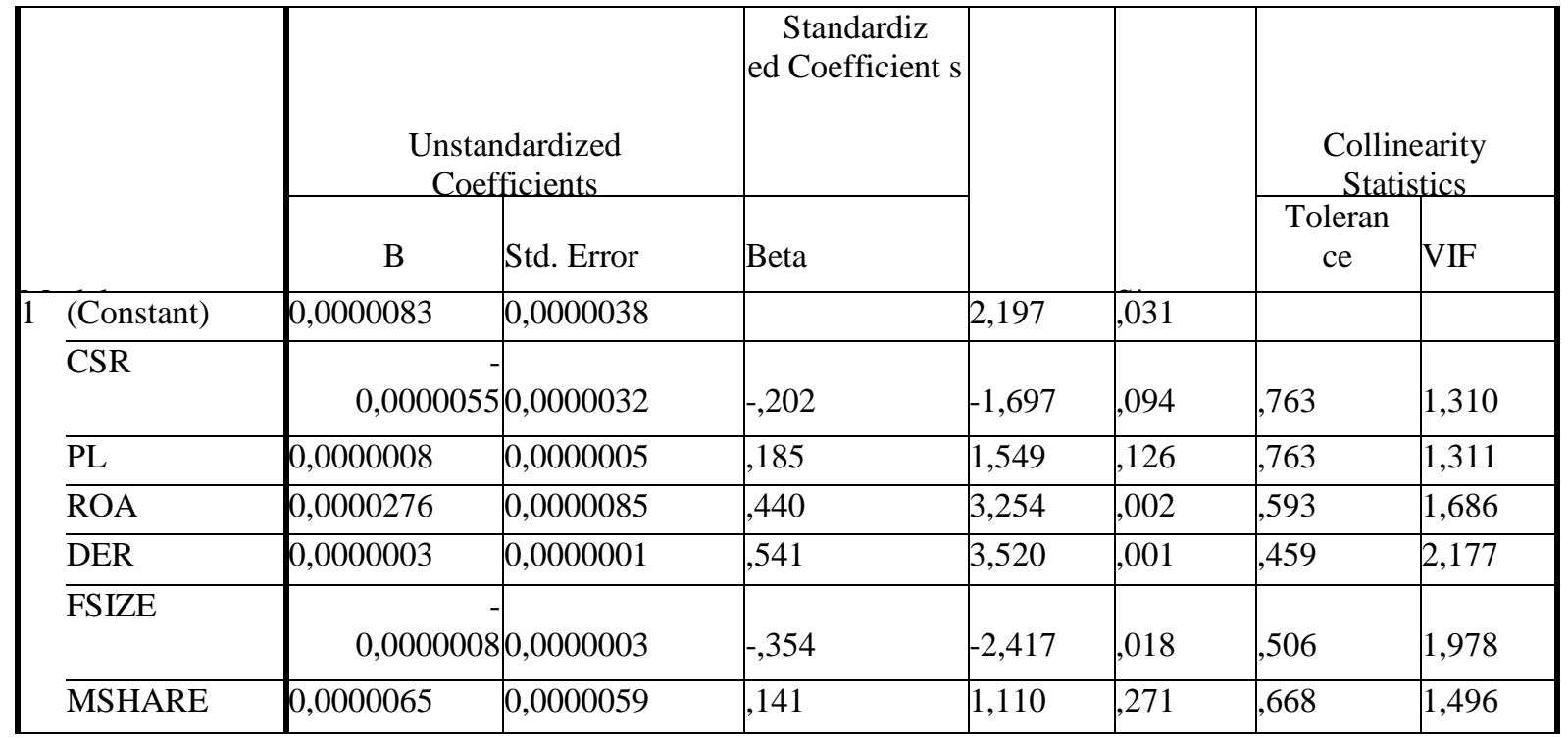

a. Dependent Variable: CAR

Sumber: Output Spss 21, 2017

Tabel 3 menunjukkan hasil pengujian multikolinearitas dan hasil dari pengujian ini menyatakan bahwa 
tidak terdapat korelasi antar variabel karena nilai tolerance (TOL) pada seluruh variabel independen menunjukkan nilai lebih dari 0,1 dan nilai VIF yang kurang dari 10.

Tabel. 4

Hasil Uji Heteroskedastisitas - Uji Glejser

Coefficients $^{\mathbf{a}}$

\begin{tabular}{|c|c|c|c|c|c|}
\hline \multirow[b]{2}{*}{ Model } & \multicolumn{2}{|c|}{$\begin{array}{l}\text { Unstandardized } \\
\text { Coefficients }\end{array}$} & \multirow{2}{*}{$\begin{array}{c}\text { Standardized } \\
\text { Coefficients }\end{array}$} & \multirow[b]{2}{*}{$\mathrm{t}$} & \multirow[b]{2}{*}{ Sig. } \\
\hline & B & Std. Error & & & \\
\hline 1 (Constant) & 0,0000016 & 0,0000019 & & ,837 & ,405 \\
\hline CSR PL & 0,0000008 & 0,0000016 & ,066 &, 503 & ,616 \\
\hline ROA & $-0,0000001$ & 0,0000003 &,- 039 &,- 300 & ,765 \\
\hline DER & $-0,0000029$ & 0,0000042 &,- 103 &,- 694 & ,490 \\
\hline FSIZE & $-0,0000001$ & 0,00000005 &,- 285 & $-1,682$ & ,097 \\
\hline MSHARE & 0,00000003 & 0,0000002 & ,030 & ,188 &, 852 \\
\hline & $-0,0000029$ & 0,0000029 &,- 139 &,- 991 & ,325 \\
\hline
\end{tabular}

Dependent Variable: ABS Sumber: Output Spss 21, 2017

Tabel 4 menunjukkan hasil pengujian heteroskedastisitas dengan melakukan uji Glejser dan menunjukkan bahwa tingkat signifikansi seluruh variabel independen terhadap variabel residual (ABSU) memiliki nilai lebih dari 0,05 sehingga dapat dikatakan setiap variabel tidak terkena

heteroskedastisitas.

Tabel. 5

\section{Hasil Uji Autokorelasi}

Model Summary

\begin{tabular}{|l|l|r|r|r|r|}
\hline $\begin{array}{l}\text { Mode } \\
1\end{array}$ & R & R Square & $\begin{array}{l}\text { Adjusted R } \\
\text { Square }\end{array}$ & $\begin{array}{l}\text { Std. Error of the } \\
\text { Estimate } \\
\text {, }\end{array}$ & $\begin{array}{r}\text { Durbin- } \\
\text { Watson }\end{array}$ \\
1 &, $491^{\mathrm{a}}$ &, 241 &, 176 &, 0000019204964 & 2,469 \\
& & & 59 &
\end{tabular}

a.

Predictors: (Constant), MSHARE, ROA, PL, CSR, FSIZE, DER

b. Dependent Variable: CAR Sumber: Output Spss 21, 2017

Tabel 5 menunjukkan hasil pengujian autokorelasi dengan melakukan pengujian Durbin Waston dan menunjukkan nilai 2,469. Hal ini menunjukkan bahwa nlai Durbin Waston berada diantara 4-du <d<4-dl, sehingga dapat dikatakan bahwa tidak terdapat autokorelasi pada data.

Tabel. 6

Hasil Uji Adjusted R-square

\begin{tabular}{|c|c|c|c|c|}
\hline \multicolumn{5}{|c|}{ Model Summary ${ }^{\text {b }}$} \\
\hline $\begin{array}{l}\text { Mode } \\
1\end{array}$ & $\mathrm{R}$ & R Square & $\begin{array}{l}\text { Adjusted R } \\
\text { Square }\end{array}$ & $\begin{array}{l}\text { Std. Error of the } \\
\text { Estimate }\end{array}$ \\
\hline 1 &, $491^{\mathrm{a}}$ & ,241 & , 176 & 000001920496459, \\
\hline
\end{tabular}

a. Predictors: (Constant), MSHARE, ROA, PL, CSR, FSIZE, DER

b. Dependent Variable: CAR Sumber: Output Spss 21, 2017 
Tabel 6 menunjukkan nilai koefisien determinasi yaitu sebesar 0,176 yang berarti bahwa variabel CSRI,PL,ROA,DER,FSIZE dan MSHARE mampu menjelaskan pengaruh Respon investor (CAR) sebesar $17,6 \%$, sedangkan sisanya dijelaskan oleh faktor-faktor lainnya.

Tabel. 7

Hasil Uji Simultan (Uji F) ANOVA ${ }^{\text {a }}$

$\mid$\begin{tabular}{lll}
\multicolumn{2}{|l|}{ Regression } &, 000 \\
1 & Residual & \\
& Total &, 000 \\
& &, 000
\end{tabular}

a. Dependent Variable: CAR

b. Predictors: (Constant), MSHARE, ROA, PL, CSR, FSIZE, DER Sumber: Output Spss 21, 2017

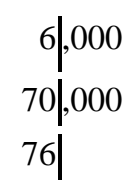<smiles>OCCC1CCCCC1</smiles>

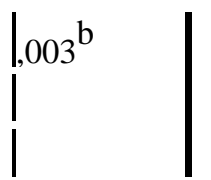

Tabel 7 menunjukkan hasil uji ANOVA atau uji $\mathrm{F}$ dan menunjukkan besarnya $\mathrm{F}$ hitung sebesar 3,704 dengan tingkat signifikansi 0,003. Hal ini menunjukkan bahwa tingkat signifikansi $\mathrm{F}$ lebih kecil dari 0,05 maka dapat dikatakan bahwa model regresi dapat digunakan untuk memprediksi perubahan variabel dependen (Respon Investor). Hal ini juga menunjukkan bahwa variabel CSRI,PL, ROA, DER, FSIZE dan MSHARE secara bersama- sama memiliki pengaruh terhadap Respon Investor (CAR).

Tabel. 8

\section{Hasil Uji Parsial(uji t) Coefficients ${ }^{a}$}

\begin{tabular}{|c|c|c|c|c|c|}
\hline \multirow[b]{2}{*}{ Model } & \multicolumn{2}{|c|}{$\begin{array}{l}\text { Unstandardized } \\
\text { Coefficients }\end{array}$} & \multirow{2}{*}{\begin{tabular}{|c}
$\begin{array}{l}\text { Standardized } \\
\text { Coefficients }\end{array}$ \\
Beta
\end{tabular}} & \multirow[b]{2}{*}{$t$} & \multirow[b]{2}{*}{ Sig. } \\
\hline & B & Std. Error & & & \\
\hline \multirow{2}{*}{$\begin{array}{l}1 \text { (Constant) } \\
\text { CSR }\end{array}$} & 0,0000083 & 0,0000038 & & 2,197 &, 031 \\
\hline & $\begin{array}{l}0,0000055 \\
0,0000008\end{array}$ & 0,0000032 &,- 202 & $-1,697$ & ,094 \\
\hline PL ROA DER & 0,0000276 & 0,0000005 &, 185 & 1,549 &, 126 \\
\hline \multirow{2}{*}{ FSIZE } & 0,0000003 & 0,0000085 &, 440 & 3,254 &, 002 \\
\hline & & $-0,0000001$ &, 541 & 3,520 &, 001 \\
\hline \multirow[t]{3}{*}{ MSHARE } & 0,0000008 & & & & \\
\hline & 0,0000065 & 0,0000003 &,- 354 & $-2,417$ &, 018 \\
\hline & & 0,0000059 &, 141 & 1,110 & 271 \\
\hline
\end{tabular}

a. Dependent Variable: CAR

Sumber: Output Spss 21, 2017

Tabel 8 menunjukkan hasil uji t dan menunjukkan nilai variabel CSR, ROA, DER, dan FSIZE lebih kecil dari 0,05 dan 0,1 yang berarti memiliki pengaruh signifikan tarhadap respon inbestor (CAR). Sedangkan variabel PL dan MSHARE menunjukkan angka lebih besar dari 0,05 dan 0,1 yaitu sebesar 0,126 dan 0,271 yang menunjukkan variabel PL dan MSHARE tidak berpengaruh terhadap Respon investor (CAR. Selain itu ditunjukkan pula bahwa CSR berpengaruh negatif terhadap Respon investor (CAR), ROA dan DER berpengaruh positif terhadap Respon investor (CAR), dan FSIZE berpengaruh negatif terhadap Respon investor (CAR).

\subsection{Pengaruh Corporate Social Responsibility (CSR) terhadap Respon Investor (CAR)}

Berdasarkan dari hasil uji hipotesis pertama menunjukkan bahwa Corporate Social Responsibility (CSR) berpengaruh negatif dan signifikan terhadap Respon Investor (CAR). CSR merupakan suatu konsep atau tindakan yang dilakukan oleh perusahaan sebagai rasa tanggung jawab perusahaan terhadap sosial maupun lingkungan sekitar dimana perusahaan itu berada, seperti melakukan suatu kegiatan yang dapat meningkatkan kesejahteraan masyarakat sekitar dan menjaga lingkungan, memberikan beasiswa untuk anak tidak mampu di daerah tersebut, dana untuk pemeliharaan fasilitas umum, sumbangan untuk membangun desa/fasilitas masyarakat yang bersifat sosial dan berguna untuk masyarakat banyak, khususnya masyarakat yang berada di sekitar perusahaan tersebut berada, Peningkatan CSR berpengaruh terhadap Respon Investor (CAR). 
Penelitian ini mendukung penelitian yang dilakukan oleh sidharta dan Juniarti (2015) yang menyatakan bahwa CSR berpengaruh negatif dan signifikan terhadap CAR.

\subsection{Pengaruh Perataan Laba (PL) terhadap Respon Investor (CAR)}

Berdasarkan dari hasil uji Hipotesis kedua menunjukkan bahwa perataan laba berpengaruh positif dan tidak signifikan terhadap Respon investor yang diproksikan dengan Cummulative Abnormal Return. Hal ini bertolak belakang dengan teori yang menyatakan bahwa semakin tinggi perataan laba maka respon yang di berikan oleh investor semakin rendah, karena profit yang diberikan kepada investor semakin rendah. Penelitian ini mendukung penelitian yang dilakukan oleh Apriwandi dan Pratama (2011) yang menyatakan bahwa Perataan laba berpengaruh positif terhadap CAR .

\subsection{Pengaruh Return on Asset (ROA) terhadap Respon Investor (CAR)}

Hasil penelitian ini menunjukkan bahwa ROA berpengaruh positif dan signifikan terhadap CAR. Hal ini membuktikan bahwa semakin tinggi ROA, menunjukkan bahwa perusahaan beroperasi semakin efisien dalam menggunakan asetnya dalam mengahasilkan laba. Oleh karena itu nilai ROA tinggi akan direspon positif oleh investor.

Penelitian ini mendukung penelitian yang dilakukan oleh sidharta dan juniarti (2015) yang menyatakan bahwa ROA berpengaruh positif dan signifikan terhadap CAR dan juga mendukung penelitian yang dilakukan oleh Anderson dan Juniarti ( 2015) yang menyatakan bahwa ROA berpengaruh positif dan signifikan terhadap CAR.

\subsection{Pengaruh Debt to equity ratio (DER) terhadap Respon Investor (CAR)}

Hasil penelitian ini membuktikan bahwa DER berpengaruh positif dan signifikan terhadap CAR. Hasil penelitian ini membuktikan bahwa semakin besar DER maka akan semakin besar return saham. Hasil penelitian ini berbeda dengan dengan penelitian yang dilakukan oleh Sidharta dan Juniarti (2015), Anderson dan Juniarti (2015), Budiman dan Juniarti (2015), Susilo dan Juniarti (2015) yang menyatakan bahwa Debt to equity ratio berpengaruh Negatif dan tidak signifikan terhadap CAR. Penelitian sidharta dan juniarti (2015) serta Anderson dan Juniarti (2015) yang mengindikasikan bahwa semakin tinggi DER menunjukkan komposisi total hutang (jangka pendek maupun jangka panjang) semakin besar dengan total modal sendiri. Sehingga berdampak semakin besar beban perusahaan terhadap pihak luar. Meningkatnya beban terhadap kreditur menunjukkan sumber modal perusahaan tergantung pada pihak luar sehingga mengurangi minat investor untuk menanamkan dananya ke perusahaan. perbedaan ini kemungkinan disebabkan variabel independen yang ditambahkan yaitu Perataan laba dimana terdapat penggolongan perusahaan menurut manajemen laba yang dilakukan.

\subsection{Pengaruh Ukuran Perusahaan (FZISE) terhadap Respon Investor (CAR)}

Hasil penelitian ini menunjukkan bahwa ukuran perusahaan

berpengaruh negatif dan signifikan terhadap Respon innvestor (CAR). Hal ini tidak membuktikan teori yang menyatakan bahwa semakin besar ukuran perusahaan berarti perusahaan tersebut memiliki sumber daya keuangan yang besar pula. Ukuran perusahaan yang besar tidak selalu memiliki risiko kegagalan lebih kecil, sehingga ukuran perusahaan direspon negatif oleh investor.

Penelitian ini mendukung penelitian yang dilakukan oleh Susilo dan Juniarti (2015) yang menyatakan bahwa Ukuran perusahaan berpengaruh negatif terhadap CAR.

\subsection{Pengaruh Market Share (MSHARE) terhadap Respon Investor (CAR)}

Hasil penelitian ini membuktikan bahwa marker share berpengaruh berpengaruh positif dan tidak signifikan terhadap CAR. Hal ini menunjukkan

bahwa posisi setiap perusahaan dalam sektor keuangan sebesar $1,37 \%$ (tabel

4.2), sehingga dapat disimpulkan bahwa posisi setiap perusahaan dalam tidak ada yang saling mendominasi sehingga investor tidak memberikan respon terhadap market share.

Penelitian ini mendukung penelitian yang dilakukan oleh Aderson dan Juniarti (2015) yang menyatakan bahwa Market share berpengaruh positif terhadap CAR.

\section{KESIMPULAN DAN SARAN}

\subsection{KESIMPULAN}

1. Corporate Social Responsibility (CSR) berpengaruh negatif dan signifikan terhadap respon investor (CAR)

2. Perataan Laba berpengaruh positif dan tidak signifikan terhadap respon investor (CAR)

3. Return on Asset (ROA) berpengaruh positif dan signifikan terhadap respon investor (CAR)

4. Debt to equity ratio (DER) berpengaruh positif dan signifikan terhadap respon investor (CAR)

5. Ukuran perusahaan (FSIZE) berpengaruh negatif dan signifikan terhadap respon investor 
(CAR)

6. Market share (MSHARE) berpengaruh positif dan tidak signifikan terhadap respon investor (CAR)

\subsection{SARAN}

Adapun beberapa saran atas hasil dari penelitian iniadalah sebagai berikut:

1. Bagi perusahaan, diharapkan dapat memperhatikan tentang pengaruh pengungkapan Corporate Social Responsibility terhadap Respon investor.

2. Bagi Akademisi,

a.Menambah tahun Penelitian untuk memperbanyak sampel agar memperoleh hasil yang lebih baik lagi.

b.untuk hasil yang maksimal sebaiknya peneliti selanjutnya meneliti Cummulative abnormal return per tahun.

3. Bagi Investor, diharapkan dapat menambah atau memperluas Khasanah keilmuan dan dapat dijadikan pertimbangan dalam mengambil kebijakan dan keputusan dalam melakukan investasi.

\section{DAFTAR PUSTAKA}

Anderson, Melissa dan Juniarti. 2015. Pengaruh Corporate Social Responsibility Terhadap Respon Investor Pada Perusahaan Non Kapitalisasi Besar (Non Big Capitalization) di Indonesia. Jurnal Business Accounting Review, Vol. 3, NO. 1, Januari 2015: 316-326.

Aprillianto, Wulandari dan Kurrohma. 2014. Pengaruh Investor saham Individual dalam Pengambilan Keputusan Investasi: Studi Hermeneutik-Kritis. Jurnal Ekonomi Bisnis dan Akuntansi, Vol. 1, 2014: 1631.

Budiman, Adrian \& Juniarti. 2015. Pengaruh Pengungkapan Corporate Social Responsibility Terhadap Respon Investor dalam sektor Perdagangan, Jasa dan Investasi. Business Accaunting Review, Vol. 3 No.2, Agustus 2015.

Ghozali, Imam. 2011. Aplikasi Analisis Multivariate Dengan Program IBM SPSS 21. Semarang : Badan Penerbit Universitas Diponegoro.

Istianingsih dan Zulni, Rhodiah. 2013. Corporate Social Responsibility Disclouser and Predictability of Future Earnings: Evidence From Indonesia Stock Exchange. Annual Internasional Conference on Accounting and Finance (AF 2013).

Kusumo, Jane Merrie Tedjo dan Juniarti. 2015. Pengaruh Corporate Social Responsibility Terhadap Respon Investor dalam Sektor Industri Barang Konsumsi. Jurnal Business Accounting Review, Vol. 3, NO. 1, Januari 2015: 212-222.

Muid, Dul . 2011. Pengaruh Corporate Social Responsibility terhadap Stock Return.

Nugraha, Dessy Arta dan Juniarti. 2015. Pengaruh Corporate Social Responsibility Terhadap Respon Investor dalam Sektor Industri Pertambangan. Jurnal Business Accounting Review, Vol. 3, NO. 1, Januari 2015: 133-143.

Ongkowijoyo, Elsa dan Juniarti. 2015. Pengaruh Corporate Social Responsibility Terhadap Respon Investor dalam Sektor Infrastruktur, Utilitas, dan Transportasi di Indonesia. Jurnal Business Accounting Review, Vol.

3, NO. 1, Januari 2015: 233-244.

Oktavia, Monica \& Juniarti. 2015. Pengaruh Corporate Social Responsibility terhadap Respon Investor dalam Sektor Pertanian. Business Accounting Review, Vol. 3, No. 2 , Agustus 2015: 1120. 
Sayekti, Y \& Wondabio. L. S. 2007. Pengaruh Corporate Social Responsibility Disclosure Terhadap Earning Response Coefficient (Suatu Studi Empiris pada Perusahaan yang terdaftar di Bursa Efek Jakarta). Simposium Nasional Akuntansi IX, Makasar. ss26-28 Juli 2007.

Sidharta, Stefany Dianita dan Juniarti. 2015. Pengaruh Corporate Social Responsibility Terhadap Respon Investor dalam Sektor Keuangan. Jurnal Business Accounting Review, Vol. 3, NO. 1, Januari 2015: 245-256.

http:/www.idx.co.id http:/www.landasanteori.com 